\title{
ANTIMICROBIAL ACTIVITY OF OREGANO (Origanum vulgare L.) AND BASIL (Ocimum basilicum L.) EXTRACTS
}

Stanislava Brđanin'1, Nemanja Bogdanović1, Marina Kolundžić1, Marina Milenković², Nataša Golić ${ }^{3}$, Milan Kojić ${ }^{3}$, Tatjana Kundakovićc ${ }^{\star}$

\footnotetext{
1 Department of Pharmacognosy, Faculty of Pharmacy, University of Belgrade, Belgrade, Serbia

2 Department of Microbiology and Immunology, Faculty of Pharmacy, University of Belgrade, Belgrade, Serbia

3 Institute of Molecular Genetics and Genetic Engineering, University of Belgrade, Belgrade, Serbia
}

The commercial samples of aerial parts of Origanum vulgare L. and Ocimum basilicum L. (Lamiaceae) were tested for antimicrobial activity. The activity of the extracts with different polarity was tested against a panel of microorganisms, including laboratory strain Helicobacter pylori NCTC 12868. The tested extracts showed a moderate activity. The extracts of $O$. vulgare were more active against bacteria, especially against Gram positive bacteria with the minimal inhibitory concentration (MIC) between 62.5 and $125 \mu \mathrm{g} / \mathrm{mL}$, than the extracts of $O$. basilicum which were active against Candida albicans (MIC $125 \mu \mathrm{g} / \mathrm{mL}$ ). Cyclohexane extract of $O$. vulgare did not show any activity against tested $H$. pylori, while all other tested extracts were active with MICs between $250 \mu \mathrm{g} / \mathrm{mL}$ and $500 \mu \mathrm{g} / \mathrm{mL}$. Identified and quantified rosmarinic acid and other polar compounds could be active antibacterial compounds in these spices.
(ORIGINAL SCIENTIFIC PAPER) UDC 582.929.4:66.061.34:579.86

Keywords: Origanum vulgare L.; Ocimum basilicum L.; antimicrobial activity; Helicobacter pylori

\section{Introduction}

Helicobacter pylori is Gram negative bacterium, one of the most common pathogens in the human stomach with the potential to cause chronic gastritis and peptic ulcer disease. In addition, persistent infection by $H$. pylori favours the development of gastric cancer [1,2]. Today a strong association between $H$. pylori infection and both cancer development and progression is known, and this is the first bacterium recognized as a class I carcinogen [3]. Eradication of $H$. pylori is successful by using the antibiotic therapy, but the resistance to antibiotics is emerging, especially to metronidazole and clarithromycin [4,5,6,7]. Natural products could be very useful in the treatment of $H$. pylori infection, but also as an adjutant to antibiotic therapy. The compounds isolated from plants could be safe and effective against both antibiotic-resistant and susceptible $H$. pylori strains, and this is the reason why the research in the field of natural products is essential.

The traditional use of plants as medicine provide the basis for suggesting that essential oils and plant extracts may be useful for specific medical conditions. The antimicrobial activity of natural compounds is well documented, including a few reports on the effects of essential oils against $H$. pylori $[8,9,10]$.

The herbs of two aromatic species $O$. vulgare $L$. and $O$. basilicum L. (Lamiaceae) are used as spices in everyday life, as well as medicine for treating different conditions, including respiratory and digestive disorders $[11,12]$. In Serbian traditional medicine, except for culinary use, O. basilicum was used as mild sedative, antihelmintic, and also against flatulence or urinary infections, while $O$. vulgare has a long tradition in the treatment of respiratory infections, gastrointestinal diseases (particularly diarrhoea) and against inflammation of skin and mucous membranes [13].

The chemistry of essential oil of $O$. vulgare and $O$. basilicum and its antimicrobial activity is well studied [14,15], as well as the chemistry and activity of different herb extracts [16]. Phenolic compounds, phenolic acids and flavonoids are major compounds of oregano and basil herb according to the literature $[11,17-22]$. Recent reports have shown a very good antimicrobial activity of the essential oils of $O$. vulgare subsp. glandulosum rich in carvacrol, while some phenolics isolated from $O$. vulgare possessed weak to moderate anti-viral activity $[11,23]$. Several reports presented the results of weak or moderate anti- $H$. pylori activity of the essential oil or different extracts of Oregano species $[8,20,24]$. Also, some reports suggested synergistic effects against $H$. pylori in vitro of phenolics from oregano and cranberry water soluble extracts $(0.1 \mathrm{mg}$ of phenolics/ disc) through urease inhibition and disruption of the energy production by inhibition of proline dehydrogenase at the plasma membrane [25].

O. basilicum is also an aromatic plant rich in essential oil and phenolic compounds (flavonoids, phenolic acids) with known antimicrobial activity. Nakhae et al. (2006) studied anti- $H$. pylori activity of $O$. basilicum extracts using the agar-diffusion method, while Castillo-Juárez et al. (2009)

\footnotetext{
* Author address: Tatjana Kundaković, Department of Pharmacognosy, Faculty of Pharmacy, University of Belgrade, Vojvode Stepe 450, 11221 Belgrade, Serbia

E-mail: ktatjana@pharmacy.bg.ac.rs

The manuscript received: September, 08, 2015.

Paper accepted: October, 07, 2015.
} 
obtained significant minimal inhibitory concentrations (MICs) of O. basilicum extracts of different polarity [26,27].

The aim of this study was to investigate the antimicrobial activity of selected commercial samples of oregano and basil, especially against $H$. pylori, and to quantify the most abundant component of the extracts, rosmarinic acid.

\section{Experimental}

\section{Chemicals and reagents}

Rosmarinic acid (RA), and standard antibiotics (ampicillin, amikacin, metronidazol, tetracycline, amoxicillin) were purchased from Sigma-Aldrich (St. Louis, MO). All organic solvents were HPLC grade and were purchased from J.T.Baker (Deventer, The Netherlands). All other reagents for antimicrobial activity testing were: Mueller-Hinton broth, antibiotic supplement, Columbia Blood Agar Base and CampyGen ${ }^{\mathrm{TM}}$ (Oxoid, Thermo Scientific, UK), glycerol (Merck, USA), yeast extract and horse blood (Torlak, Belgrade, Serbia), casitone (Difco, USA), RPMI-1640 medium (Sigma, St. Louis, MO, USA), 10\% heat inactivated foetal bovine serum FBS (GIBCO, Thermo Fisher Scientific, Life Technologies). All other reagents were from Sigma (St. Louis, MO).

\section{Plant extract preparation}

The commercial samples of aerial parts of $O$. vulgare L. and O. basilicum L. (Lamiaceae) were purchased (Institute for Medicinal Plant Research "Josif Pančić", Belgrade) and used for the antimicrobial test. The air-dried, powdered aerial parts (10 g-basil; 10 g-oregano) were extracted with cyclohexane during three days on room temperature $(1: 5$, two times, successively). After filtration, the plant material was dried and extracted with dichloromethane and methanol using the same procedure. The solvent was evaporated under low pressure and dried to obtain $\mathrm{C}_{6} \mathrm{H}_{12}(0.0817 \mathrm{~g})$, $\mathrm{CH}_{2} \mathrm{Cl}_{2}(0.1153 \mathrm{~g})$ and $\mathrm{MeOH}$ extracts $(0.3958 \mathrm{~g})$ of $\mathrm{O}$. vulgare and $\mathrm{C}_{6} \mathrm{H}_{12}(0.0946 \mathrm{~g}), \mathrm{CH}_{2} \mathrm{Cl}_{2}(0.1760 \mathrm{~g})$ and $\mathrm{MeOH}$ extracts of $\mathrm{O}$. basilicum $(0.3422 \mathrm{~g})$. The methanol extract was used for quantification of rosmarinic acid (RA) and all three extracts for antimicrobial analysis.

Quantification of rosmarinic acid in the plant extract

HPLC separation was performed using a Agilent 1100 Series system equipped with a G-1312A binary pump, a G-1328B injector (20 $\mu \mathrm{L}$ loop) and G1315B DAD detector. The column used was a ZORBAX Eclipse XDB-C18 $(4.6 \times 250 \mathrm{~nm}, 5 \mu \mathrm{m})$ and operated at the temperature of $25{ }^{\circ} \mathrm{C}$. A gradient elution was performed with solvent $A$ $\left(\mathrm{H}_{2} \mathrm{O}\right.$ and $\left.\mathrm{H}_{3} \mathrm{PO}_{4}, \mathrm{pH}=2.8\right)$ and $\mathrm{B}$ (solvent $\mathrm{A}$ : acetonitrile) as follows: $10-25 \% \mathrm{~B}$ (5 min), 25\% B isocratic (10 min), 25$30 \%$ B (5 min), 30-50\% B (5 min), 50-70\% B (5 min), 70$10 \% \mathrm{~B}(5 \mathrm{~min})$ at a flow rate of $0.8 \mathrm{~mL} / \mathrm{min}$. The injection volume was $20 \mu \mathrm{L}$. The presence of RA was identified on the bases of its retention time and UV spectra, as well as by direct comparison with the standard. Quantification of RA was performed under the same condition; detection wavelength was $320 \mathrm{~nm}$. All chromatographic operations were carried out at room temperature. The calibration curve was constructed with five concentrations of standard solutions of RA. Within the concentration range of $0.100-1 \mathrm{mg} / \mathrm{mL}$, the relationship between the peak area of RA was linear with a regression equation $y=27071 x-457.5$ ( $x$ - concentration of RA; $y$ - peak area of RA). The retention time of standard substance RA was $18.8 \mathrm{~min}$. The linearity of the calibration curve was verified by the correlation coefficient ( $r 2=0.9998$ ). Each measurement was performed in triplicates. The concentration of $5 \mathrm{mg} / \mathrm{mL}$ of the methanol extract of $O$. vulgare and $O$. basilicum in acetonitrile and water $(40: 60, V / V)$ was used to calculate the amount of RA.

\section{Antimicrobial activity}

For antimicrobial testing, methanol, dichlormethane and cyclohexane extracts were used. The screening of antimicrobial activity of the tested extracts samples was evaluated using nine different laboratory strains of bacteria - Gram positive: Staphylococcus aureus (ATCC 25923), S. epidermidis (ATCC 12228), Micrococcus luteus (ATCC 9341), Bacillus subtilis (ATCC 6633), Enterococcus feacalis (ATCC 29212) and Gram negative: Escherichia coli (ATCC 25922), Klebsiella pneumoniae (NCIMB 9111), Pseudomonas aeruginosa (ATCC 27853), Salmonella abony (ATCC 13076) and one strain of the yeast Candida albicans (ATCC 10231). The broth microdilution method was used to determine minimal inhibitory concentrations (MICs) of the tested extracts according to Clinical and Laboratory Standards Institute [28]. These tests were performed in Müller-Hinton broth for bacteria and in Sabouraud dextrose broth for Candida. Test strains were suspended in medium to give a final density of $2.0 \times 10^{6} \mathrm{cfu} / \mathrm{mL}$. The samples of the extracts were dissolved in dimethylsulfoxide (DMSO) in concentrations of $1.0 \mathrm{mg} / \mathrm{mL}$. Serial dilutions of the stock solutions in broth medium were prepared in a microtitre plate (96 wells). The MIC was defined as the lowest concentration of the extract at which the microorganism does not demonstrate a visible growth. All antimicrobial tests were performed in duplicate and two positive growth controls were included. The MICs of ampicillin and amikacin were determined in parallel experiments.

\section{Anti-Helicobacter pylori activity}

Laboratory strain of H. pylori (NCTC 12868) was used as an indicator for the detection of antimicrobial activity of plant extracts. H. pylori was maintained at $-80{ }^{\circ} \mathrm{C}$ in MuellerHinton Broth supplemented with $10 \%$ horse blood and $20 \%$ $(\mathrm{v} / \mathrm{v})$ glycerol until required for experiments. Before being used, the strain was subcultured twice on Columbia Blood Agar Base supplemented with $0.5 \%(\mathrm{w} / \mathrm{V})$ yeast extract, $1 \%(\mathrm{w} / \mathrm{V})$ casitone, $10 \%(\mathrm{v} / \mathrm{v})$ horse blood and antibiotic supplement. Plates were incubated for $72 \mathrm{~h}$ at $37^{\circ} \mathrm{C}$ under microaerophilic conditions in a jar with CampyGenTM. Colonies were suspended in RPMI-1640 medium supplemented with $10 \%$ heat inactivated foetal bovine serum and $0.5 \%$ yeast extract to achieve the turbidity requested for the antimicrobial test. Metronidazol, tetracycline and amoxicillin were used as standard antibiotics. 
Determination of MIC by Agar Dilution Method

Antimicrobial activity of the plant extracts was followed on plates prepared as described above. Two-fold dilutions of each plant extract were prepared in RPMI-1640 medium. The strains were plated on agar plates and $10 \mu \mathrm{l}$ drops of twofold dilutions of the plant extracts were spotted on the plates in triplicates. The plates were incubated at $37^{\circ} \mathrm{C}$ under microaerophilic conditions (CampyGenTM). The plates were examined visually after $72 \mathrm{~h}$ of incubation. The minimal inhibitory concentration was defined as the lowest concentration of the extract inhibiting the visible bacterial growth. Metronidazol, tetracycline and amoxicillin showed ten-fold lower activity than the extracts with MIC values $\leq$ $0.625 \mathrm{mg} / \mathrm{ml}$.

\section{Results and discussion}

Determination of rosmarinic acid content

Rosmarinic acid was previously isolated from oregano extracts by different authors [11,29,30], and concerned previously as an important antioxidant and antimicrobial agent. Park et al. (2011) determined the content of RA in herb extracts of different Lamiaceae species and found that the percentage was between $0.22-0.97 \%$, while Shekarchi et al. (2012) showed the content of $25.0 \pm 0.1 \mathrm{mg} / \mathrm{g}$ of dried $O$. vulgare $[29,31]$. Austrian plants of $O$. vulgare contained from $0.6-37.2 \mathrm{mg} / \mathrm{g}$ dry mass, while Lithuanian plants possessed the maximum value of $9.7 \mathrm{mg} / \mathrm{g}$ dry mass in the flower extract [32,33].

The quantity of RA in different tissues of $O$. basilicum grown in vitro or in hydroponic culture was different. RA ranged approximately from 4 to $63 \mathrm{mg} / \mathrm{g} \mathrm{DW}$ [21] or in phenolics rich extracts $3.2 \mathrm{mg} / \mathrm{g}$ extract [19]. In commercial samples of methanolic extracts of oregano and basil, different concentrations of RA and other phenolics were determined after (basil: 14.59-86.01 mg/100 g; oregano: 2.04-575.80 mg/100 g) [3]. Our results have shown that the content of RA in oregano was $14 \mathrm{mg} / \mathrm{g}$ and basil $2.4 \mathrm{mg} / \mathrm{g}$. Concerning the wide range of previously obtained results, commercial samples of oregano and basil were in accordance with literature data.

\section{Antimicrobial activity}

Tested extracts showed a moderate antimicrobial activity. Their MIC values are presented in Table 1. Antimicrobial activity of rosmarinic acid was published before by Stanojković et al. (2013) and MIC values for antibacterial activity were $0.0125-0.1 \mathrm{mg} / \mathrm{mL}$ [34]. Antifungal activity was stronger with MICs $0.0125-0.05 \mathrm{mg} / \mathrm{mL}$. Antibiotics were more active than the tested extracts. The MIC values of antibiotics are presented in Table 2.

The obtained MIC values for bacteria, except $H$. pylori were between 62.5 and $125 \mu \mathrm{g} / \mathrm{mL}$ for $O$. vulgare extracts, and 125 and $250 \mu \mathrm{g} / \mathrm{mL}$ for $O$. basilicum extracts. The extracts of $O$. vulgare were more active against bacteria, especially against Gram positive bacteria (except $B$. subtilis) than the extracts of $O$. basilicum which were active against C. albicans (MIC $125 \mu \mathrm{g} / \mathrm{mL}$ ). Dichlormethane and metha- nol extracts of $O$. vulgare were more active against $S$. typhimurium (MIC $62.5 \mu \mathrm{g} / \mathrm{mL}$ ) than corresponding extracts of O. basilicum (MIC $250 \mu \mathrm{g} / \mathrm{mL}$ ).

Table 1. Antimicrobial activity of tested $O$. vulgare and $O$. basilicum extracts (MIC $\mu \mathrm{g} / \mathrm{mL}$ )

\begin{tabular}{lcccccc}
\hline \multicolumn{1}{c}{ Bacteria } & OVC & OVD & OVM $^{*}$ & OBC & OBD & OBM \\
\hline $\begin{array}{l}\text { Staphylococcus aureus } \\
\text { ATCC 6538 }\end{array}$ & 125 & 125 & 62.5 & 125 & 125 & 125 \\
$\begin{array}{l}\text { S. epidermidis } \\
\text { ATCC 12228 }\end{array}$ & 62.5 & 125 & 62.5 & 125 & 125 & 125 \\
$\begin{array}{l}\text { Micrococcus luteus } \\
\text { ATCC 9431 }\end{array}$ & 62.5 & 125 & 62.5 & 125 & 125 & 125 \\
$\begin{array}{l}\text { Bacillus subtilis } \\
\text { ATCC 6633 }\end{array}$ & 125 & 125 & 125 & 250 & 250 & 125 \\
$\begin{array}{l}\text { Escherichia coli } \\
\text { ATCC 25922 } \\
\text { Klebsiella pneumoniae }\end{array}$ & 125 & 125 & 125 & 250 & 250 & 250 \\
$\begin{array}{l}\text { NCIMB 9111 } \\
\begin{array}{l}\text { Pseudomonas } \\
\text { aeruginosa ATCC 9027 }\end{array}\end{array}$ & 125 & 125 & 125 & 125 & 125 & 125 \\
$\begin{array}{l}\text { S. typhimurium } \\
\text { ATCC 14028 }\end{array}$ & 125 & 62.5 & 62.5 & 250 & 250 & 250 \\
$\begin{array}{l}\text { Helicobacter pylori } \\
\text { NCTC 12868 } \\
\text { Candida albicans }\end{array}$ & $>1000$ & 500 & 250 & 500 & 250 & 500 \\
ATCC 10231 & $>500$ & $>500$ & 125 & 125 & 125 & 125 \\
\end{tabular}

ATCC 1023

*OV- O. vulgare extracts; OB - O. basilicum extracts (C-cyclohexane, D- dichloromethane, M-methanol)

Previous studies were focused on the antimicrobial activity of essential oils of oregano and basil. A strong antimicrobial activity attributed to present phenolic compounds i.e. carvacrol, thymol and linalool $[14,15,16,35]$. There were less researches concerning antimicrobial activity of oregano or basil extracts. Because of toxic effects of carvacrol and thymol (oregano), and estragol (basil) that are concentrated in the essential oils, testing of these extracts can have practical application [36].

The recent paper of Martins et al. (2014) showed a moderate antibacterial activity of the ethanol extract of oregano herb in the concentration of $20 \mathrm{mg} / \mathrm{mL}$ against Gram negative bacteria E. coli, $P$. aeruginosa, E. sakazakii and $P$. vulgaris [37]. The other authors showed that methanol extract of $O$. basilicum did not have any antibacterial activity even in the concentrations which were higher than $2640 \mathrm{mg} / \mathrm{mL}$ [38].

Cyclohexane extract of $O$. vulgare did not show any activity against tested $H$. pylori, while all other tested extracts were active with MICs between $250 \mu \mathrm{g} / \mathrm{mL}$ (methanol extract of $O$. vulgare and dichlormethane extract of $O$. basilicum) and $500 \mu \mathrm{g} / \mathrm{mL}$ (cyclohexane and methanol extract of $O$. basilicum; dichlomethane extract of $O$. vulgare). $O$. basilicum and $O$. vulgare extracts were moderate active, with the strongest activity of dichlormethane and methanol extracts suggesting that polar compounds were the most active compounds. Ethnopharmacological survey of anti-H. pylori pylori activity of different aromatic plants showed that $O$. majorana ethanol extract 
possessed activity against seven clinical isolates of $H$. pylori in the concentration of $250-500 \mu \mathrm{g} / \mathrm{ml}$ [20]. Ohno et al. (2003) showed in vitro inhibitory activity against $H$. pylori growth at the concentration of $0.1 \%(\mathrm{~V} / \mathrm{V})$ of $O$. majorana and 0 . basilicum album essential oils [8].

Table 2. Antimicrobial activity of tested antibiotics (MIC $\mu \mathrm{g} / \mathrm{mL}$ )

\begin{tabular}{|c|c|c|c|c|c|}
\hline \multirow[b]{2}{*}{ Bacteria } & \multicolumn{5}{|c|}{ MIC $\mu \mathrm{g} / \mathrm{mL}$} \\
\hline & Ampicillin & Amikacin & Amoxicillin & Tetracycline & Metronidazole \\
\hline Staphylococcus aureus & 0.5 & n.t. ${ }^{*}$ & - & - & - \\
\hline \multicolumn{6}{|l|}{ ATCC 6538} \\
\hline S. epidermidis & 0.5 & n.t. & - & - & - \\
\hline \multicolumn{6}{|l|}{ ATCC 12228} \\
\hline Micrococcus luteus & 1.5 & n.t. & - & - & - \\
\hline \multicolumn{6}{|l|}{ ATCC 9431} \\
\hline Bacillus subtilis & 1.8 & n.t. & - & - & - \\
\hline \multicolumn{6}{|l|}{ ATCC 6633} \\
\hline Escherichia coli & 2.0 & 1.5 & - & - & - \\
\hline \multicolumn{6}{|l|}{ ATCC 25922} \\
\hline Klebsiella pneumoniae & 2.8 & 2.0 & - & - & - \\
\hline \multicolumn{6}{|l|}{ NCIMB 9111} \\
\hline Pseudomonas & n.t. & 2.5 & - & - & - \\
\hline \multicolumn{6}{|l|}{ aeruginosa ATCC 9027} \\
\hline S. typhimurium & n.t. & n.t. & - & - & - \\
\hline \multicolumn{6}{|l|}{ ATCC 14028} \\
\hline Helicobacter pylori & - & - & $<62.5$ & $<62.5$ & $<62.5$ \\
\hline \multicolumn{6}{|l|}{ NCTC 12868} \\
\hline Candida albicans & - & - & - & - & - \\
\hline ATCC 10231 & & & & & \\
\hline
\end{tabular}

The relatedness between antimicrobial activity and phenolic compounds present in some plants was already observed when using microorganisms other than $H$. pylori. The results of Chun et al. (2005) showed that aqueous (50 mg phenolics per disk) and ethanol extracts of cloned $O$. vulgare against $H$. pylori ATCC 43504 than commercial samples (100 mg of phenolics) [39]. The authors concluded that a higher antioxidant activity as well as higher phenolics content could be the reason for anti$H$. pylori activity due to different mechanisms. Methanol extracts of $O$. dictamnus, O. majorana and $O$. vulgare from Greece exhibited a moderate antimicrobial activity against 15 clinical isolates of $H$. pylori with MICs $0.625-5$ $\mathrm{mg} / \mathrm{mL}$ [24]. Similar results were obtained with 0 . basilicum methanol extract (MIC 2.5-5 mg/mL). Our results for O. vulgare extracts could be comparable with the results of Mahady et al. (2005) who showed very low MICs in vitro of methanol extracts of $O$. majorana herb and $O$ vulgare against 14 clinical isolates and 1 ATCC strains (50-100 $\mu \mathrm{g} / \mathrm{mL})$ [40], because all other authors obtained much higher MIC values.

Different Ocimum species were tested against $H$. pylori and for gastroprotective activity $[41,42,43]$. MICs of the extracts against 4 most sensitive clinical isolates of $H$. pylori were 677 and $729 \mu \mathrm{g} / \mathrm{mL}$. Very low MICs $(31.2 \mu \mathrm{g} /$ $\mathrm{ml}$ ) were obtained for the methanol extract of $O$. basilicum from Mexico [27], and for methanol, n-hexane and butanol fraction of $O$. basilicum methanol extract from Iran $(39.1,41$ and $117.2 \mu \mathrm{g} / \mathrm{ml})$, while aqueous fraction did not have any activity against tested clinical isolates of $\mathrm{H}$. pylori [26]. Our results for tested basil extracts were between 250 and $500 \mu \mathrm{g} / \mathrm{mL}$ against standard $H$. pylori strain. It was obvious from the literature that clinical isolates of $H$. pylori were more sensitive to tested O. basilicum and $O$. vulgare extracts.

Rosmarinic acid was the major compound in tested methanol extracts. A previous study of Lin et al. (2005) considered the synergistic effects against $H$. pylori in vitro of phenolics from oregano and cranberry water soluble extracts $(0.1 \mathrm{mg}$ of phenolics/disc) through urease inhibition from one side and disruption of the energy production on the other. The inhibition of proline dehydrogenase at the plasma membrane was linked with higher-molecular-weight phenolics from oregano which operated at the plasma membrane level and subsequently, upon urease inhibition [25]. Also, partial hydrophobicity of phenolics of oregano may allow the attachment and inhibition at the plasma membrane level.

As a major phenolic in oregano methanol extract, rosmarinic acid could be involved in exhibited activity. Even in the content of RA in oregano $14 \mathrm{mg} / \mathrm{g}$ and basil 2.4 $\mathrm{mg} / \mathrm{g}$ for commercial samples and with very high antiHelicobacter pylori activity, we can conclude that rosmarinic acid was not the only active compound in the tested methanol extracts. Some other compounds were probably involved in anti-H. pylori activity.

\section{Conclusion}

Origano and basil are very common spices in every day diet and could be important in both prevention and treatment of many diseases, including bacterial infection. As a rich source of phenolic compounds and other secondary metabolites with antimicrobial activity, they could be subjected for further preventive role in $\mathrm{H}$. pylori infection in vivo, and to chemical structure determination of active compounds.

\section{Acknowledgments}

The authors are grateful to the Ministry of Education, Science and Technological Development of Serbia for financial support (Grant Nos 173021 and TR 34012).

\section{References}

[1] H. De Reuse, D. Vinella, C. Cavazza, Common themes and unique proteins for the uptake and trafficking of nickel, a metal essential for the virulence of Helicobacter pylori, Frontiers in Cellular and Infection Microbiology, 3 (2013) 1-6.

[2] L.E. Wroblewski, R.M. Peek, K.T. Wilso, Helicobacter pylori and Gastric Cancer: Factors That Modulate Disease Risk, Clinical Microbiology Review, 23 (2010) 713-739.

[3] J. Lee, Caffeic acid derivatives in dried Lamiaceae and Echinacea purpurea products, Journal of Functional Foods, 2 (2010) 158-162. 
[4] T.K. Ling, A.F. Cheng, J.J. Sung, P.Y. Yiu, S.S. Chung, An increase in Helicobacter pylori strains resistant to metronidazole: a five-year study, Helicobacter 1 (1996) 57-61.

[5] S. Matsumoto, Y. Washizuka, Y. Matsumoto, S. Tawara, F. Ikeda, Y. Yokota, M. Karita, Appearance of a metronidazole-resistant Helicobacter pylori strain in an infected-ICR-mouse model and difference in eradication of metronidazole-resistant and - sensitive strains, Antimicrobial Agents and Chemotherapy, 41 (1997) 26022605.

[6] P.D. Midolo, M.G. Korman, J.D. Turnidge, J.R.Lambert Helicobacter pylori resistance to tetracycline, Lancet, 347 (1996) 1194-1195.

[7] J. Versalovic, D. Shortridge, K. Kibler, M.V. Griffy, J. Beyer, R.K. Flamm, S.K. Tanaka, D.Y. Graham, M.F. Go. Mutations in 23S rRNA are associated with clarithromycin resistance in Helicobacter pylori, Antimicrobial Agents and Chemotherapy, 40 (1996) 477-480.

[8] T. Ohno, M. Kita, Y. Yamaoka, S. Imamura, T. Yamamoto, S. Mitsufuji, T. Kodama, K. Kashima, J. Imanishi, Antimicrobial activity of essential oils against Helicobacter pylori. Helicobacter, 8 (2003) 207-215.

[9] H. Imai, K. Osawa, H. Yasuda, H. Hamashima, T. Arai, M. Sasatsu, Inhibition by the essential oils of peppermint and spearmint of the growth of pathogenic bacteria, Microbios, 106 (2001) 31-39.

[10] E. Kalpoutzakis, N. Aligiannis, A. Mentis, S. Mitaku, C. Charvala, Composition of the essential oil of two Nepeta species and in vitro evaluation of their activity against Helicobacter pylori, Planta Medica, 67 (2001) 880-883.

[11] X.-L. Zhang, Y.-S. Guo, C.-H. Wang, G.-Q. Li, J.-J. Xu, H.Y. Chung, W.-C. Ye, Y.-L. Li, G.- C. Wang, Phenolic compounds from Origanum vulgare and their antioxidant and antiviral activities, Food Chemistry, 152 (2014) 300306.

[12] K. Singletary, Oregano: Overview of the literature on health benefits, Nutrition Today, 45 (2010) 129-138.

[13] J. Tucakov, Lečenje biljem, Kultura, Beograd, 1971, pp. 247-248, 281-283

[14] E. De Falco, E. Mancini, G. Roscigno, E. Mignola, O. Taglialatela-Scafati, F. Senatore, Chemical composition and biological activity of essential oils of Origanum vulgare L. subsp. vulgare L. under different growth conditions, Molecules, 18 (2013) 14948-14946.

[15] M.K. Stefanakis, E. Touloupakis, E. Anastasopoulos, D. Ghanotakis, H.E. Katerinopoulos, P. Makridis, Antibacterial activity of essential oils from plants of the genus Origanum, Food Control, 34 (2013) 539-546.

[16] B.Z. Ličina, O.D. Stefanović, S.M. Vasić, I.D. Radojević, M.S. Dekić, L.R. Čomić, Biological activities of the extracts from wild growing Origanum vulgare L., Food Control, 33 (2013) 498-504.

[17] G. Esen, A.D. Azaz, M. Kurkcuoglu, K.H.C. Baser, A. Tinmaz, Essential oil and antimicrobial activity of wild and cultivated Origanum vulgare L. subsp. hirtum (Link) letswaart from the Marmara region, Turkey, Flavour and Fragrance Journal, 22 (2007) 371-376.

[18] L. Faleiro, G. Miguel, S.Gomes, L. Costa, F. Venâncio, A. Teixeira, A.C. Figueiredo, J.G. Barroso, L.G. Pedro, Antibacterial and antioxidant activities of essential oils isolated from Thymbra capitata L. (Cav.) and Origanum vulgare L., Journal of Agricultural and Food Chemistry, 53 (2005) 8162-8168.
[19] H. Harnafi, M. Ramchoun, M. Tits, J.-N. Wauters, M. Frederich, L. Angenot, M. Aziz, C. Alem, S. Amrani, Phenolic acid-rich extract of sweet basil restores cholesterol and triglycerides metabolism in high fat dietfed mice: A comparison with fenofibrate, Biomedicine and Preventive Nutrition, 3 (2013) 393-397.

[20] S. Karakaya, S.N. El, N. Karagözlü, S. Şahin, Antioxidant and antimicrobial activities of essential oils obtained from Oregano (Origanum vulgare ssp. hirtum) by using different extraction methods, Journal of Medicinal Food, 14 (2011) 645-652.

[21] S.F.H. Zaidi, K. Yamada, M. Kadowaki, K. Usmanghani, T. Sugiyama, Bactericidal activity of medicinal plants, employed for the treatment of gastrointestinal ailments, against Helicobacter pylori, Journal of Ethnopharmacology, 121 (2009) 286-291.

[22] C. Kiferle, M. Lucchesini, A. Mensuali-Sodi, R. Maggini, A. Raffaelli, A. Pardossi, Rosmarinic acid content in basil plants grown in vitro and in hydroponics, Central European Journal of Biology, 6 (2011) 946-957.

[23] Y. Lu, B. Gao, P. Chen, D. Charles, L. Yu, Characterisation of organic and conventional sweet basil leaves using chromatographic and flow-injection mass spectrometric (FIMS) fingerprints combined with principal component analysis, Food Chemistry, 154 (2014) 262-268.

[24] G. Stamatis, P. Kyriazopoulos, S.Golegou, A. Basayiannis, S. Skaltsas, H. Skaltsa, In vitro anti-Helicobacter pylori activity of Greek herbal medicines, Journal of Ethnopharmacology, 88 (2003) 175-179.

[25] Y.T. Lin, Y.I. Kwon, R.G. Labbe, K. Shetty, Inhibition of Helicobacter pylori and associated urease by oregano and cranberry phytochemical synergies, Applied and Environmental Microbiology, 71(2005) 8558-8564.

[26] M.M. Nakhaei, F. Malekzadeh, M. Khaje-Karamoddin M. Ramezani, In vitro anti-Helicobacter pylori effects of sweet basil (Ocimum basilicum L.) and purple basil (Ocimum basilicum var. purpurascens) Pakistan Journal of Biological Sciences, 9 (2006) 2887-2891.

[27] I. Castillo-Juárez, V. González, H. Jaime-Aguilar, G. Martínez, E. Linares, R. Bye, I. Romero, Anti-Helicobacter pylori activity of plants used in Mexican traditional medicine for gastrointestinal disorders, Journal of Ethnopharmacology, 122 (2009) 402-405.

[28] Clinical and Laboratory Standards Institute (CLSI 2007) 2007. Performance standards for antimicrobial susceptibility testing, 17th Informational Supplement. Approved Standard. CLSI document M100-S17. Wayne, PA, USA (2007).

[29] B. Park, Identification and quantification of a major antioxidant and anti-inflammatory phenolic compound found in basil, lemon thyme, mint, oregano, rosemary, sage, and thyme, International Journal of Food Science and Nutrition, 62 (2011) 577- 584.

[30] N. Nakatani, Phenolic antioxidants from herbs and spices, Biofactors, 13 (2000), 141-146.

[31] M. Shekarchi, H. Hajimehdipoor, S. Saeidnia, A.R. Gohari, M.P. Hamedani, Comparative study of rosmarinic acid content in some plants of Labiatae family, Pharmacognosy Magazine, 8 (2012) 37-41.

[32] B. Lukas, C. Schmiderer, J. Novak, Phytochemical diversity of Origanum vulgare L. subsp. vulgare (Lamiaceae) from Austria, Biochemical Systematics and Ecology, 50 (2013) 106-113.

[33] J. Radusiene, L. Ivanauskas, V. Janulis, V. Jakstas, 
Composition and variability of phenolic compounds in Origanum vulgare from Lithuania, Biologija, 54 (2008) 4549.

[34] T. Stanojković, B. Kolundžija, A. Ćirić, M. Soković, D. Nikolić, T. Kundaković, Cytotoxicity and antimicrobial activity of Satureja kitaibelii Wierzb. Ex Heuff (Lamiaceae), Digest Journal of Nanomaterials and Biostructures, 8 (2013) 845-854.

[35] U. Ravid, E. Putievsky, I. Katzir, E. Lewinsohn, Enantiomeric Composition of Linalol in the Essential Oils of Ocimum Species and in Commercial Basil Oils, Flavour and Fragrance Journal, 12 (1997) 293-296.

[36] M. De Vincenzia, M. Silanob, F. Maialettia, B. Scazzocchioa, Safety Data Review, Constituents of aromatic plants: II. Estragole, Fitoterapia, 71 (2000) 725-729.

[37] Martins N, Barros L, Santos-Buelga C, Henriques M, Silva S, Ferreira IC, Decoction, infusion and hydroalcoholic extract of Origanum vulgare L.: Different performances regarding bioactivity and phenolic compounds, Food Chemistry, 158 (2014) 73-80.

[38] N.S. Alzoreky, K. Nakahara, Antibacterial activity of extracts from some edible plants commonly consumed in Asia, International Journal of Food Microbiology, 80 (2003) 223-230.
[39] S.-S. Chun, D. A. Vattem, Y.-T. Lin, K. Shety, Phenolic antioxidants from clonal oregano (Origanum vulgare) with antimicrobial activity against Helicobacter pylori, Process Biochemistry, 40 (2005) 809-816.

[40] G.B. Mahady, S.L. Pendland, A. Stoia, F.A. Hamill, D. Fabricant, B.M. Dietz, L.R. Chadwick, In vitro susceptibility of Helicobacter pylori to botanical extracts used traditionally for the treatment of gastrointestinal disorders, Phytotherapy Research, 19 (2005) 988-991.

[41] G. Schmeda-Hirschmann, E. Yesilada, Traditional medicine and gastroprotective crude drugs, Journal of Ethnopharmacology, 100 (2005) 61-66.

[42] G.E. Bergonzelli, D. Donnicola, N. Porta, I.E. CorthésyTheulaz, Essential oils as components of a diet-based approach to management of Helicobacter infection, Antimicrobial Agents and Chemotherapy, 47 (2003) 32403246.

[43] P.V. Tan, C. Mezui, M. Boda, Anti-Helicobacter and gastroduodenal cytoprotective actions of the leaf aqueous extract of Ocimum suave (Lamiaceae), Journal of Medicinal Plant Research, 5 (2011) 5958-5966.

Izvod

\section{ANTIMIKROBNA AKTIVNOST EKSTRAKATA ORIGANA (Origanum vulgare L.) I BOSILJKA (Ocimum basilicum L.)}

Stanislava Brđanin ${ }^{1}$, Nemanja Bogdanović1, Marina Kolundžić1 ${ }^{1}$, Marina Milenković2 Nataša Golić ${ }^{3}$, Milan Kojić ${ }^{3}$, Tatjana Kundaković ${ }^{1}$

${ }^{1}$ Katedra za farmakognoziju, Farmaceutski fakultet, Univerzitet u Beogradu, Beograd, Srbija

2 Katedra za mikrobiologiju i imunologiju, Farmaceutski fakultet, Univerzitet u Beogradu, Beograd, Srbija

3 Institut za molekularnu genetiku i genetičko inženjerstvo, Univerzitet u Beogradu, Beograd, Srbija

Komercijalni uzorci nadzemnih delova Origanum vulgare L. i Ocimum basilicum L. (Lamiaceae) su korišćeni za određivanje antimikrobne aktivnosti. Aktivnost ekstrakata različite polarnosti je testirana protiv izabranih mikroorganizama, uključujući laboratorijski soj Helicobacter pilori NCTC 12868. Testirani ekstrakti su imali umerenu aktivnost. Ekstrakti $O$. vulgare su bili aktivniji protiv bakterija, posebno Gram pozitivnih bakterija sa minimalnim inhibitornim koncentracijama (MIK) između 62,5 i $125 \mu \mathrm{g} / \mathrm{mL}$, od ekstrakata O. basilicum koji su pokazali aktivnost protiv Candida albicans (MIK $125 \mu \mathrm{g} / \mathrm{mL}$ ). Cikloheksanski ekstrakt O. vulgare nije pokazao antimikrobnu aktivnost na testirani $H$. pylori, dok su ostali testirani ekstrakti bili aktivni sa MIK vrednostima između $250 \mu \mathrm{g} / \mathrm{mL}$ i $500 \mu \mathrm{g} / \mathrm{mL}$. Identifikovana i kvantifikovana ruzmarinska kiselina i druga polarna jedinjenja mogu predstavljati aktivna jedinjenja sa antibakterijskom aktivnošću u ovim začinima.
UDK 582.929.4:66.061.34:579.86

Ključne reči: Origanum vulgare L.; Ocimum basilicum L.; antimikrobna aktivnost; Helicobacter pylori 